\title{
Measurable Tumor Indicator
}

National Cancer Institute

\section{Source}

National Cancer Institute. Measurable Tumor Indicator. NCI Thesaurus. Code C161482.

An indication as to whether a measurable tumor is present. 